\title{
The problem of solid waste on the tourist trails of Tatra National Park, Poland
}

\author{
Paweł Religa \& Sylwia Adach
}

Keywords: biodiversity, naturalness, protected area, restorativeness, scenic beauty, waste management

\section{Abstract}

Litter left behind on tourist trails is a persistent problem in national parks, regardless of the country in which the park is situated. The present article analyses the amount of waste on tourist trails in the most popular natural park in Poland, Tatra National Park (TNP), a small area of a mountainous character which is heavily used by tourists. Tourists who use the Tatra trails leave from 140 to $180 \mathrm{~m}^{3}$ solid waste there per year. Its presence in parks, as well as being unsightly, is a potential risk for fauna and flora. $90 \%$ of the waste collected from the trails in TNP is hard or non-biodegradable waste. The waste from TNP's tourists trails needs to be considered in its totality, as recyclable fractions make up about $70 \%$ of all rubbish disposed of, and so areas such as TNP should be subject to organized waste management. It was found that the particular strategy implemented significantly affects the amount of waste from the tourist trails that is actually collected and disposed of. The key element for the efficient functioning of the waste-management strategy is the consistent implementation of an action plan that takes into account the specific nature of the area and the principles under which it is made available to tourists. Particularly significant are the frequency and regularity with which rubbish is removed. Moreover, there is a need to raise public awareness regarding waste left on tourists trails in TNP.
Profile

Protected area

Tatra National Park

Mountain range

Carpathians

Country

Poland

\section{Introduction}

One of the top structures for protecting nature is the national park - an area that protects natural resources and processes of extraordinary value, where nature is relatively well preserved (Ciocănea et al. 2016). The main purpose of creating national parks is to preserve biological diversity, resources, landscape formations and components of inanimate nature, and the beauty of the landscape, or to restore damaged natural habitats (Arpin \& Cosson 2015; Grazhdani 2016). Although a national park is first and foremost a natural asset, it is also a public asset (He et al. 2018; Repka \& Švecová 2012; Weaver \& Lawton 2017; Zhou \& Edward Grumbine 2011). Humans are therefore present in national parks, because they are made available for tourist purposes (D'Antonio et al. 2013; Kuo \& Yu 2001; Peng et al. 2017). In these areas where unique natural values are protected, a dynamic increase in tourist traffic has been observed for some years (Tolvanen \& Kangas 2016; Wang et al. 2019).

National parks are made accessible under strict and precise rules (Tuvi et al. 2011; Wang et al. 2019), which include the creation of trails and other tourist, educational and management facilities (D'Antonio et al. 2013; Kidd et al. 2015; Pickering et al. 2010). Making national parks open to the public in this manner brings numerous benefits. For example, it contributes to the development of the region, and the creation of jobs (Imran et al. 2014; Mutanga et al. 2015; Thapa Karki 2013; Tuvi et al. 2011). However, negative impacts of human presence on these environmentally valu- able areas have also been observed (Díez Gutiérrez et al. 2017; Ghoddousi et al. 2018; Tolvanen \& Kangas 2016). In addition to such manifestations of human pressure as the destruction of flora and soil on the trails and in their vicinity (D'Antonio et al. 2013; Kidd et al. 2015; Pickering et al. 2010), noise (Iglesias Merchan et al. 2014) and air pollution, human presence in protected areas also brings the problem of littering (Hu et al. 2018b; Kuniyal et al. 2003; Pickering et al. 2010; Zhong et al. 2011).

Visiting natural parks, especially mountain parks, is very popular in Poland. The main challenges connected with effective waste management in protected areas in Poland include: 1) the large number of tourists exploring the relatively small areas of parks made available for tourist purposes, and 2) the limitation or even total prohibition of the introduction of any type of infrastructure in the territory of parks, including communal infrastructure such as waste bins or toilets. This is a consequence of the parks' main role, which is the preservation of their environmental value. It means that no action undertaken in such areas may have a negative impact on fauna and flora or intrude on the landscape (Hu et al. 2018a). Therefore, the basic communal infrastructure is situated, as a rule, only by park entrances, in selected places close to tourist, educational and management facilities and, in exceptional cases, along a limited number of heavily used tourist trails. Such limited solutions are insufficient to solve the problem of littering on tourist trails, because of shortcomings in public attitudes to, and their behaviour within, nature and national parks (Wang et al. 


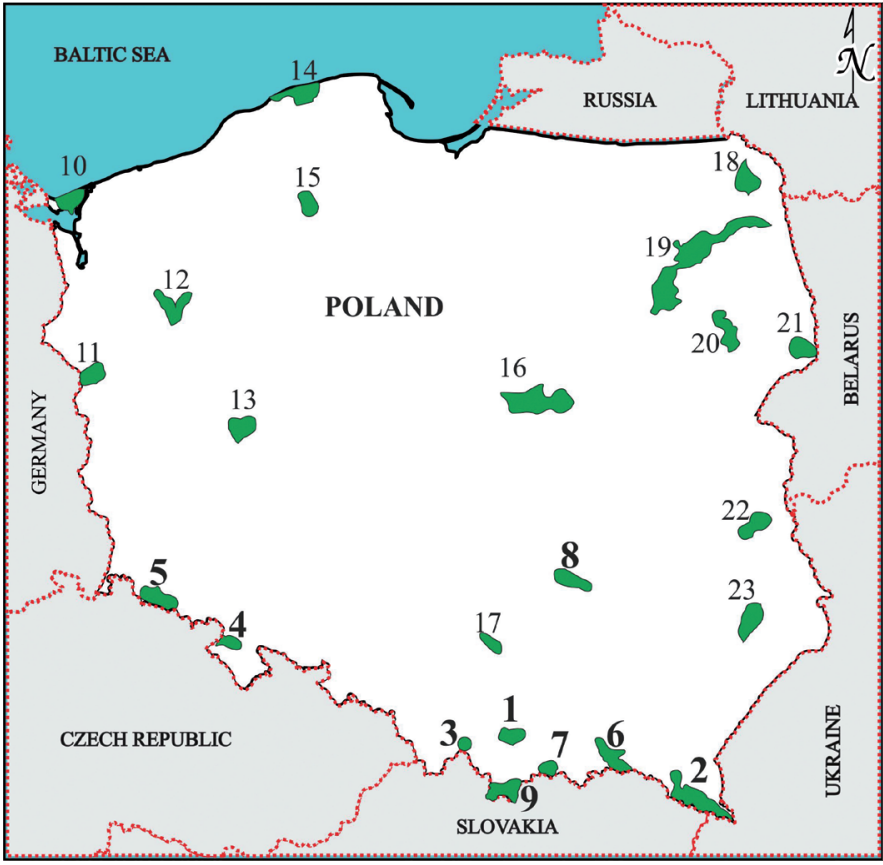

\author{
Legend \\ ….. - state border \\ Y - National Parks \\ 1-23 - number of National Park
}

Figure 1 - National Parks in Poland.

2019). Rubbish persists on the trails and in their vicinity, and the problem is especially visible in mountain parks that are popular among tourists, where - additionally - waste collection and transport are difficult due to the topography (Hu et al. 2018a, b). In the literature, discussions of littering in valuable natural areas associated with tourist traffic are increasingly frequent. They indicate a large amount and variety of waste in these areas. The authors focus mainly on identifying ways to reduce waste (Almeida Cunha 2010; Hu et al. 2018b) and, by identifying common types of waste, indicate directions for recycling or re-use (Kaseva \& Moirana 2010). However, defining the most effective waste-collection and removal strategy for litter on tourist trails has still not been solved. Knowing the factors that influence the sometimes temporary nature

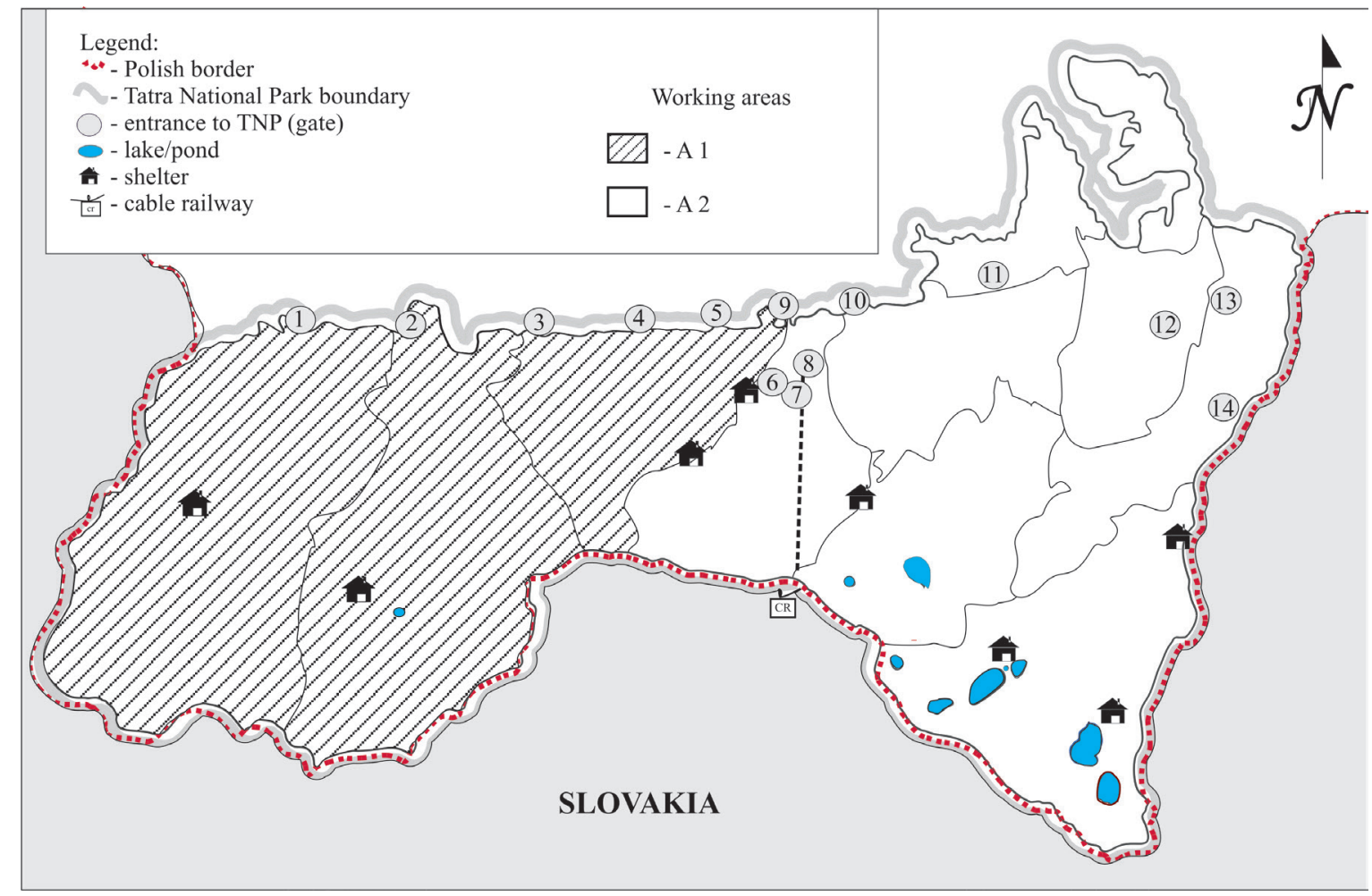

Figure 2 - Division of Tatra National Park into areas subject to different strategies for waste removal from tourist trails. 
Table 1 - Quantity of waste collected on tourist trails in TNP.

\begin{tabular}{|r|r|r|r|l|}
\hline Year & \multicolumn{3}{|l|}{$\begin{array}{l}\text { Volume of annual waste in } \\
\mathbf{m}^{3} \text { collected from }\end{array}$} & $\begin{array}{l}\text { Estimated annual } \\
\text { number of tourists } \\
\text { visiting TNP }\end{array}$ \\
\cline { 2 - 4 } & $\begin{array}{l}\text { working } \\
\text { area A1 }\end{array}$ & $\begin{array}{l}\text { working } \\
\text { area A2 }\end{array}$ & $\begin{array}{l}\text { TNP as } \\
\text { a whole }\end{array}$ & \\
\hline 2012 & 72 & 107 & 179 & 3135346 \\
\hline 2013 & 79 & 100 & 179 & 2942493 \\
\hline 2014 & 61 & 87 & 148 & 3091645 \\
\hline 2015 & 63 & 86 & 149 & 3356526 \\
\hline 2016 & 59 & 122 & 181 & 3689743 \\
\hline 2017 & 56 & 98 & 154 & 3788171 \\
\hline
\end{tabular}

of littering in some places along tourist trails and its space-distribution more generally is a prerequisite for effective waste management in parks.

Littering on tourist trails in protected areas presents a great threat for the natural environment; waste encountered on trails and in their vicinity also gives a bad aesthetic impression. Therefore, such areas need to be subject to organized waste management. This article presents the results of a quantitative analysis of solid waste on the trails in Tatra National Park (TNP), the most popular natural park in Poland. On the basis of the analysis of the quantity of waste and the volume of tourist traffic in the years 2012-2017 in TNP, and in the light of the various waste management systems, we discuss the dynamics of the littering of hiking trails. The purpose of the research was to indicate important factors for planning waste management strategy, especially waste collection and removal from tourist trails. In the future, these factors will help improve the waste management system both in TNP and in similar protected areas.

\section{Characteristics of the research area}

There are 23 national parks in Poland. However, almost $60 \%$ of tourists visiting a national park choose as their destination one of the 9 parks that have a mountainous character (Statistics Poland, 2018). For many years, TNP (Figure 1) has been the most visited among them (and, indeed, is the most popular NP in Europe). TNP is the only high-mountain, alpine region in Poland. The area is thus characterized by its great altitudinal range, vertical climatic belts, particular fauna and flora species, and numerous streams and small rivers.

In TNP there are $275 \mathrm{~km}$ of marked tourist trails of diverse degrees of difficulty, from very easy to very demanding and requiring the use of safety equipment. Entry fees apply and tickets may be purchased at 14 points of sale at the entrances to the park, most of which are open all year round (Tatra National Park 2019).

\section{Systems for collecting and removing waste from the trails in Tatra National Park}

Tourists who come to the park leave waste behind, on the tourist trails and in their vicinity (in the buffer zone of a trail, a band about $5 \mathrm{~m}$ wide on both sides of a trail if the field conditions are suitable), at organized and non-organized stopping points on a trail, at viewing points, and near information boards. This waste is collected and removed according to two different strategies which take into account the characteristics of the area and involve either park staff and volunteers or an outside company. In creating its overall strategy, the TNP was divided into two areas: the western area (A1) and the eastern area (A2) (Figure 2).

The western area (A1) is characterized by a number of easy trails accessible for the average tourist, notably by so-called mass tourists represented by school groups, families with children, and the elderly. Other trails are relatively long, and the majority of tourists, consequently, do not use them. Below the summit belt, there are vast valleys with trails perfect for walking: hardened ground, many places to rest, communal infrastructure, and transport possibilities (carriages, bikes). The trails leading through the valleys are the main attraction of this part of the Tatra mountains.

The eastern area (A2) covers the highest part of the Tatra mountains. Many trails are difficult to access. This area includes the greatest tourist attractions of the Polish Tatra mountains: small mountain lakes, including Morskie Oko and Pięć Stawów Polskich; the highest peak, Rysy (2499 m a.s.l.); and the symbol of the Podhale Region, Giewont (1 $894 \mathrm{~m}$ a.s.l.). The trails leading to the main tourist attractions, despite their significant degree of difficulty, are exploited extensively. Consequently, many improvements have been made: hardened ground, many resting places, communal infrastructure. Additionally, there is a cable railway in this area, which allows mass tourist exploration of most peaks in the region, despite the fact that the trails are very difficult.

The collection and removal of waste from the trails in A2 is outsourced by TNP to third-party companies, and the work is carried out by qualified employees. From April to November, the so-called high tourist season, rubbish is removed from the trails with variable frequency - from 4 to 20 times a month. From June to September, litter-picking along the main trails is carried out every day. During the low tourist season (November - March), due to the limited accessibility of the park because of weather conditions, the litterpicking is done by the parks' employees, with limited frequency and only along some trails.

The trails in A1 are cleared of litter by park employees together with volunteers. This is done, all year 

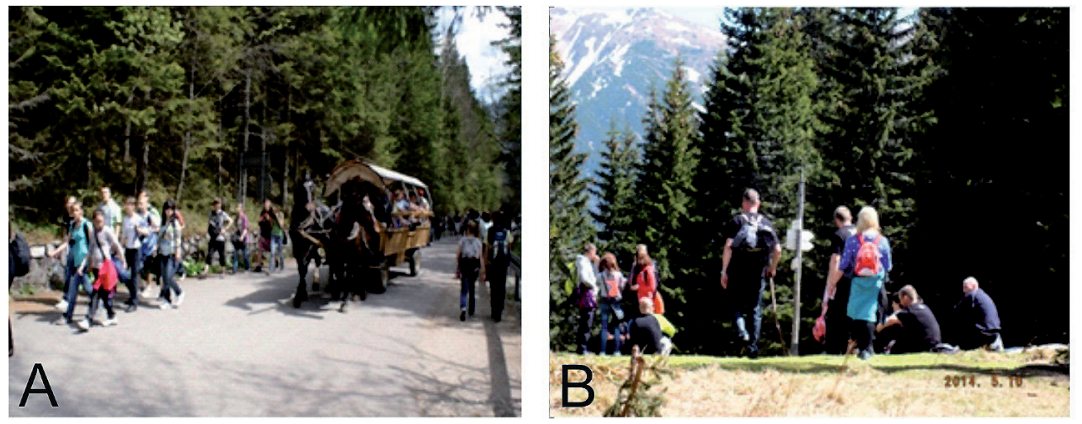

Figure 3 - Tourists in Tatra National Park: $A$ - route to Morskie Oko; B - Iwaniacka Pass. (C) P. Religa

round, on an ad-hoc basis, both in terms of frequency, and in terms of the specific trail which is cleared.

Rubbish from the trails is collected using special grippers, which allow litter located in otherwise inaccessible places to be collected. The rubbish is put, unsorted, into disposable bags of various sizes, which are then carried or transported outside the park. Next, it is transferred for further processing as mixed waste.

\section{Methodology}

Quantity and types of waste removed from the tourist trails in Tatra National Park

The quantity of waste collected from TNP's tourist trails between 2012 and 2017 (Table 1) was analysed.

Due to the varying moisture content of the waste, which depends on the weather conditions, the quantity was expressed as a volume. The quantity of waste was estimated according to the number of bags of $120 \mathrm{dm}^{3}$ filled with rubbish. Prior to measurement, the waste was partly crushed. It was not sorted, but was transferred for further processing as mixed waste.

For types of waste, the rubbish was divided into four fractions: plastic, glass, metal and other waste. The volume of each fraction was then determined. Finally, the percentage share of each type of waste was calculated.

\section{Tourist traffic in TNP}

Each year TNP is visited by an average of about 3 million tourists (Figure 3). For the last several years, the number has been growing slowly but steadily.

The number of tourists using the trails in TNP is controlled by selling tickets at points of sale at the park's entrances (Figure 2). Some authorized persons are allowed free entry. The number of ticketless entries to use the park's trails is growing each year. These entries constitute on average $2 \%$ of the total number of tick- ets issued each year. Additionally, tourists may enter TNP using the cable car located in the western area of the park.

\section{Estimated annual quantity of waste}

In order to combine parameters for the number of tourists and the amount of waste, the VWT (volume of waste per tourist) parameter was used. This parameter presents the dynamics of littering hiking trails in a mountain protected area. We have not found any other suitable solution in the literature.

Based on the data for the amount of waste collected from the tourist trails in TNP and the number of tourists who used the trails in 2012-2017, the VWT was calculated according to the following formula:

$$
\mathrm{VWT}=\mathrm{V}_{\mathrm{c}} / \mathrm{N}
$$

$\mathrm{V}_{c}$... annual volume of waste collected from the tourist trails at the park $\left[\mathrm{m}^{3} /\right.$ year $]$

$\mathrm{N}$... annual number of tourists using the trails in TNP [people/year]

The average volume was calculated using the formula:

$\overline{\mathrm{a}}=\frac{\mathrm{VWT}_{2012}+\ldots+\mathrm{VWT}_{\mathrm{n}}}{\mathrm{n}}$

$\mathrm{VWT}_{\mathrm{n}} \ldots$ volume of waste per tourist in the particular year $\left[\mathrm{m}^{3} /\right.$ person]

$\mathrm{n}$... number of years

The standard deviation was calculated using the formula:

$$
S D=\sqrt{\frac{\sum_{i=1}^{n}\left(V W T_{2012}-\bar{a}\right)^{2}+\ldots+\left(V W T_{n}-\bar{a}\right)^{2}}{n(n-1)}}
$$

\begin{tabular}{|c|c|c|c|c|c|c|c|c|c|}
\hline \multirow[t]{2}{*}{ Area } & \multirow[t]{2}{*}{ Unit } & \multicolumn{6}{|c|}{$\begin{array}{l}\text { Unit of volume of waste per tourist } \\
\text { (VWT } \times 10^{-5} \text { ) }\end{array}$} & \multirow[t]{2}{*}{\begin{tabular}{|l|} 
Average \\
Volume
\end{tabular}} & \multirow{2}{*}{\begin{tabular}{|l|} 
Standard \\
deviation \\
$\left(\mathrm{SD} \times 10^{-6}\right)$
\end{tabular}} \\
\hline & & \begin{tabular}{|l|}
2012 \\
\end{tabular} & \begin{tabular}{|l|}
2013 \\
\end{tabular} & 2014 & 2015 & 2016 & 2017 & & \\
\hline$\overline{\mathrm{A} 1}$ & \multirow{3}{*}{ 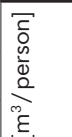 } & 6.26 & 7.16 & 5.51 & 5.39 & 4.49 & 4.33 & 5.52 & 4.37 \\
\hline A2 & & 5.36 & 5.45 & 4.36 & 3.90 & 5.16 & 3.92 & 4.69 & 2.93 \\
\hline Entire TNP & & 5.69 & 6.09 & 4.77 & 4.42 & 4.92 & 4.06 & 4.99 & 3.13 \\
\hline
\end{tabular}

Table 2 -Estimated volume of waste left by an average tourist on trails in TNP. 


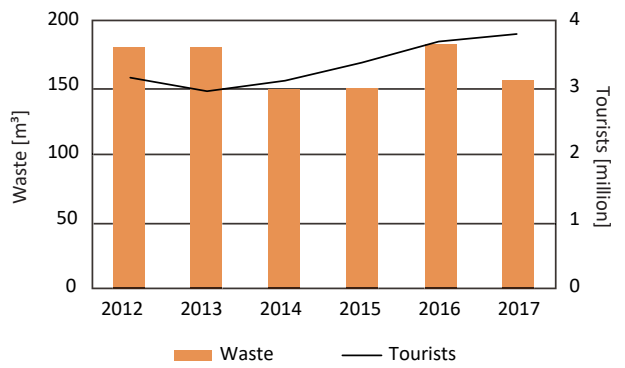

Figure 4 - Quantity of waste collected from the park's trails compared with the numbers of tourists visiting TNP, 20122017.

The VWT, average volume and standard deviation are presented in Table 2.

\section{Results and Discussion}

Analysis of the quantity of waste on the trails in TNP

The number of visitors to TNP is growing every year (Figure 4). Tourists who use the Tatra trails leave waste there, the amount of which varies between 140 and $180 \mathrm{~m}^{3}$ per year. However, it can be observed both that for the last few years the quantity of rubbish removed from the trails has been lower than it was at the beginning of this decade (2012), and that it has been more or less constant, despite the ever-increasing numbers of tourists visiting TNP.

For the last several years, TNP has been conducting intensive educational campaigns to raise tourists' awareness of the negative impact of littering on the natural environment. These campaigns are aimed at all age groups (children, young people, adults) from various backgrounds and are widely publicized by regional and national media. Recent campaigns appear to have had a significant effect in reducing the park's waste and they should be continued.

Analysis of the types of waste on the trails in TNP

Studies of the types of rubbish classified as other waste (Figure 5) indicate more or less constant fractions in relation to the total quantity of waste (approximately $30 \%$ of the total amount of waste). Other waste includes cigarette butts, packaging (paper, foil, disposable materials), clothing and its elements, paper tissues and organic waste. It is characterized by considerable heterogeneity of material and high humidity (Hu et al. 2018a).

Other fractions are glass, plastic and metal. The share of glass is fairly stable and is around $20 \%$. This fraction is made up mostly by bottles. The proportion of plastics, however, increases noticeably from year to year. This fraction is composed mainly of different types of drinks packaging (Hu et al. 2018b), the popularity of which is due mainly to their low weight and the availability of different sizes to meet different

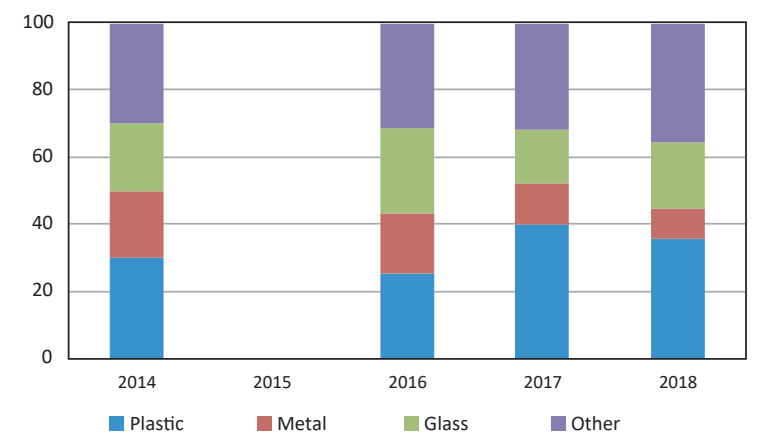

Figure 5-Types of solid waste collected from the tourist trails in TNP.

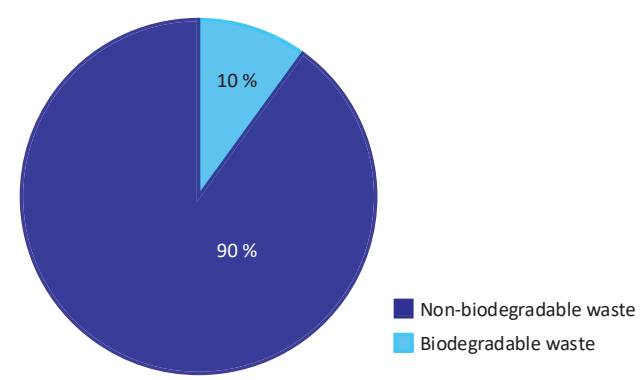

Figure 6 - Biodegradable and non-biodegradable fractions of the solid waste collected from the tourists trails in TNP.

requirements (Kaseva \& Moirana 2010; Kuniyal et al. 2003). Plastic waste currently accounts for about $40 \%$ of all waste collected from TNP's routes. By contrast, the share of the metals waste group is constantly decreasing.

The analysis of the material composition of the waste shows that the rubbish removed from TNP is largely made of recoverable materials, which can be recycled. As can be seen in Figure 5, fractions that can be recycled make up about $70 \%$ of all waste that is disposed of. Such results indicate that there is a need to promote the idea of selective waste collection by the park's employees or volunteers directly from tourist trails - a strategy of so-called in-situ collection and sorting of waste before it is disposed of.

The analysis of the waste collected in TNP also shows that $90 \%$ is hard or non-biodegradable waste (Figure 6). A similar situation is observed in other national parks (Kuniyal et al. 2003). Due to their longevity in the environment, their removal from national parks is imperative. In addition to being unsightly, their presence is a potential risk for fauna and flora (Almeida Cunha 2010; Xavier da Silva et al. 2018).

Amount of waste on trails depending on the waste management strategy

As described in Section 3 above, in TNP there are two independent systems for collecting and removing waste from the tourist trails. The rubbish from the trails in A2 is collected and removed by third-party companies and follows a pre-determined schedule. The trails in A1 are cleared by park employees and vol- 

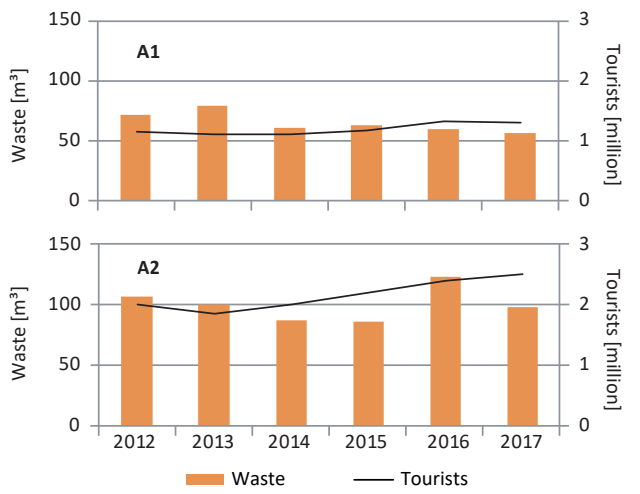

Figure 7 - Quantity of waste collected on trails in relation to number of tourists visiting TNP in 2012-2017, depending on the waste management strategy ( $A 1$ and $A 2$ ).

unteers, on an ad-hoc basis in terms both of frequency and of the specific trail being cleared.

Figure 7 presents changes in the amount of waste collected from the trails in relation to the number of tourists visiting TNP in the years 2012-2017 and depending on the waste management strategy. In A1, it can be seen that the number of tourists and the quantity of waste they leave on the trails are more or less constant.

In A2, the situation is totally different. First of all, it can be seen that the number of tourists using the trails is constantly growing, because this part of TNP is much more attractive for tourists. The situation also results from the improved accessibility of various parts of the park: modernization of the cable railway, and increasing the number and quality of the resting places located along the tourist trails. Although the number of tourists in this area has increased significantly, no significant increase in the amount of waste on the trails has been observed. Nevertheless, the amount of rubbish removed from the trails fluctuates significantly from year to year, by as much as $36 \mathrm{~m}^{3}$, or approximately $35 \%$ of the average total amount of waste collected in this area in the course of a year.
The situation results from a change of waste collection company as a result of the tender procedure, in which new calls for tender are put out annually. The analysis (Figure 5) suggests differences in performance between the companies who win the tenders. The most significant element here is probably how well a trail's 'buffer zone' is cleared of litter. The results indicate the need for additional regular, thorough clearing of litter from these zones.

According to our calculations, the average volume of waste left on trails by tourists visiting TNP is decreasing year on year (Figure 8). The total amount of waste has decreased by more than $30 \%$ over the last five years. It may also be noted that the VWT values differ between areas according to which waste management system is in force. For A1, the VWT coefficients are higher than those for A2.

Irregular removal of litter from the trails, which is characteristic in A1, may give an impression of a lack of attention to their cleanliness. This in turn lowers the sense of personal responsibility and encourages undesired behaviour (Wang et al. 2019). The consequence is a greater quantity of rubbish on the trails. Thus the amount of waste left on trails by tourists visiting TNP is affected by the particular waste management strategy in place.

The differences in the values of the VWT coefficient may also be affected by the density of tourist traffic on trails. The more tourists there are around, the higher the sense of responsibility for one's behaviour, which results from a sense of a loss of anonymity. The presence of other tourists discourages some behaviours, while also shaping characteristic, ecofriendly attitudes (Chiu et al. 2014). This conclusion is confirmed by the lower values of the VWT coefficient for A2, where there are more tourists, than for A1 (Figure 8).

\section{Conclusion}

Littering tourist trails in protected areas poses a great threat for the natural environment. The most

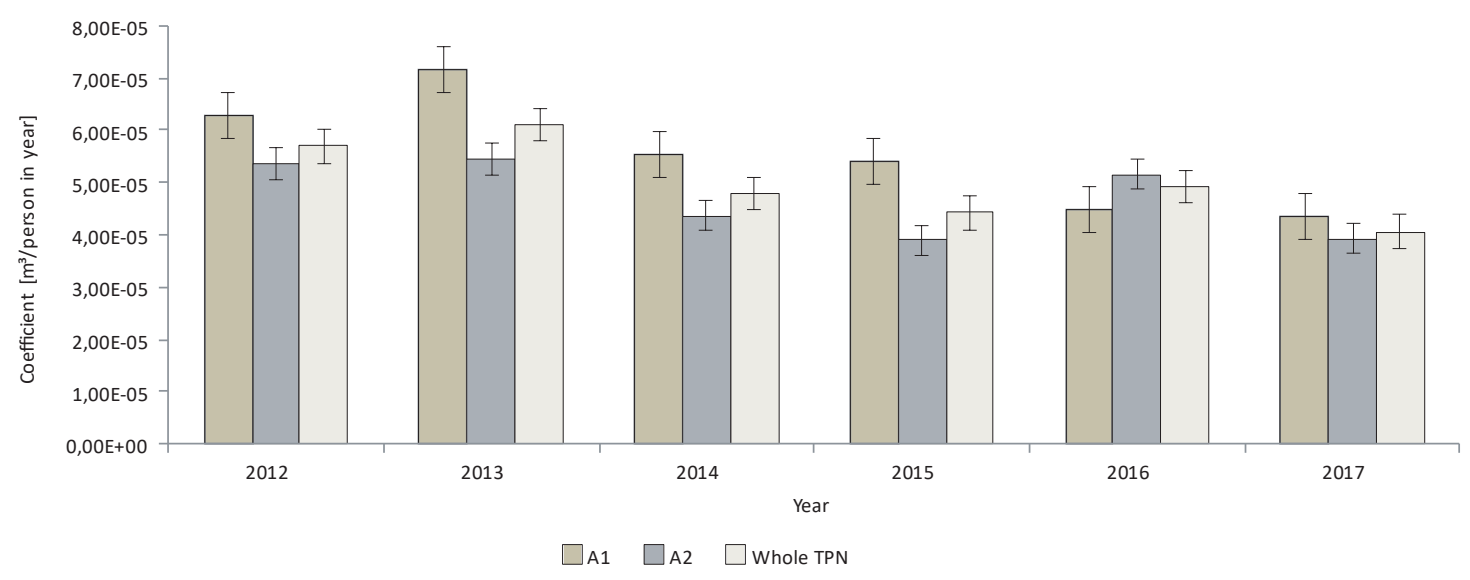

Figure 8-Changes in the volume of waste left by an average tourist on trails in TNP. 
popular park in Poland, and simultaneously the most popular park in Europe, is TNP, which attracts more than 3 million tourists every year.

Tourists who use the Tatra trails leave waste there, the amount varying between 140 and $180 \mathrm{~m}^{3}$ per year. However, it can be observed that the total amount of waste removed is more or less constant, despite the constantly growing number of tourists visiting TNP.

$90 \%$ of the waste collected from the tourist trails in TNP is hard or non-biodegradable waste. Due to its persistence in the environment, this waste must be removed from national parks where, as well as being unsightly, it creates potential risks for fauna and flora. Most of the waste removed from TNP (about 70\%), however, is made of recyclable materials. Therefore, such areas as TNP should be subject to organized waste management.

Based on the analysis of the two different waste management systems in TNP, it may be concluded that the particular strategy in use has a significant impact on the amount of waste that tourists leave behind. Particularly significant here are the frequency and regularity with which rubbish is removed. Based on our analyses, it seems that an efficient waste management system in parks with a mountainous terrain requires attention to be paid to the parks' level of cleanliness. Moreover, there is a need to introduce a strategy of separating rubbish in situ into recyclable and general waste.

As well as an appropriate action plan, an efficient waste management system within a protected area involves educational campaigns targeted at different social groups exploring the area.

\section{Acknowledgements}

The authors would like to thank the Administration of the Tatra National Park for providing access to the information necessary for preparation of the present article.

\section{References}

Almeida Cunha, A. 2010. Negative effects of tourism in a Brazilian Atlantic forest National Park. Journal for Nature Conservation 18: 291-295.

Arpin, I. \& A. Cosson 2015. The category of mountain as source of legitimacy for national parks. Environmental Science and Policy 49: 57-65.

Arsić, S., D. Nikolić \& Z. Živković 2017. Hybrid SWOT - ANP - FANP model for prioritization strategies of sustainable development of ecotourism in $\mathrm{Na}$ tional Park Djerdap, Serbia. Forest Policy and Economics 80: 11-26.

Central Statistical Office 2018. Statistics Poland. Available at: https://stat.gov.pl/en/topics/ environment-energy/environment/
Chiu, Y.T.H., W.I. Lee \& T.H. Chen 2014. Environmentally responsible behavior in ecotourism: Antecedents and implications. Tourism Management 40: 321-329.

Ciocănea, C.M., C. Sorescu, M. Ianoşi \& V. Bagrinovschi 2016. Assessing Public Perception on Protected Areas in Iron Gates Natural Park. Procedia Environmental Sciences 32: 70-79.

D’Antonio, A., C. Monz, P. Newman, S. Lawson \& D. Taff 2013. Enhancing the utility of visitor impact assessment in parks and protected areas: A combined social-ecological approach. Journal of Environmental Management 124: 72-81.

Díez Gutiérrez, M., T. Tørset, E. Skjetne, \& J. Odeck 2017. Tourist traffic simulation as a protected area management tool. The case of Serengeti National Park in Tanzania. Tourism Management Perspectives 22: 54-63.

Ghoddousi, S., P. Pintassilgo, J. Mendes, A. Ghoddousi \& B. Sequeira 2018. Tourism and nature conservation: A case study in Golestan National Park, Iran. Tourism Management Perspectives 26: 20-27.

Goh, E., B. Ritchie J. Wang 2017. Non-compliance in national parks: An extension of the theory of planned behaviour model with pro-environmental values. Tourism Management 59: 123-127.

Grazhdani, D. 2016. Assessing the variables affecting on the rate of solid waste generation and recycling: An empirical analysis in Prespa Park. Waste Management 48: 3-13.

He, S., Y. Su, L. Wang, L. Gallagher \& H. Cheng 2018. Taking an ecosystem services approach for a new national park system in China. Resources, Conservation and Recycling 137: 136-144.

Hu, H., J. Zhang, G. Chu, J. Yang \& P. Yu 2018a. Factors influencing tourists' litter management behavior in mountainous tourism areas in China. Waste Management 79: 273-286.

Hu, H., J. Zhang, C. Wang, P. Yu \& G. Chu 2018b. What influences tourists' intention to participate in the Zero Litter Initiative in mountainous tourism areas: A case study of Huangshan National Park, China. Science of The Total Environment 657: 1127-1137.

Iglesias Merchan, C., L. Diaz-Balteiro \& M. Soliño 2014. Noise pollution in national parks: Soundscape and economic valuation. Landscape and Urban Planning 123: 1-9.

Imran, S., K. Alam \& N. Beaumont 2014. Environmental orientations and environmental behaviour: Perceptions of protected area tourism stakeholders. Tourism Management 40: 290-299.

Kaseva, M.E. \& J.L. Moirana 2010. Problems of solid waste management on Mount Kilimanjaro: A challenge to tourism. Waste Management \& Research 28: 695-704.

Kidd, A.M., C. Monz, A. D’Antonio, R.E. Manning, N. Reigner, K.A. Goonan \& C. Jacobi 2015. The effect of minimum impact education on visitor spatial 
behavior in parks and protected areas: An experimental investigation using GPS-based tracking. Journal of Environmental Management 162: 53-62.

Kuniyal, J.C., A.P. Jain \& A.S. Shannigrahi 2003. Solid waste management in Indian Himalayan tourists' treks: A case study in and around the Valley of Flowers and Hemkund Sahib. Waste Management 23: 807-816.

Kuo, N.W. \& Y.H. Yu 2001. An investigation of the environmental loads of shei-pa national park in Taiwan. Environmental Geology 40: 312-316.

León, C.J., J. de León, J.E. Araña \& M.M. González 2015. Tourists' preferences for congestion, residents' welfare and the ecosystems in a national park. Ecological Economics 118: 21-29.

Liu, J., Z. Ouyang \& H. Miao 2010. Environmental attitudes of stakeholders and their perceptions regarding protected area-community conflicts: A case study in China. Journal of Environmental Management 91: 2254-2262.

Mateu-Sbert, J., I. Ricci-Cabello, E. Villalonga-Olives \& E. Cabeza-Irigoyen 2013. The impact of tourism on municipal solid waste generation: The case of Menorca Island (Spain). Waste Management 33: 2589_ 2593.

Mutanga, C.N., S. Vengesayi, N. Muboko \& E. Gandiwa 2015. Towards harmonious conservation relationships: A framework for understanding protected area staff-local community relationships in developing countries. Journal for Nature Conservation 25: 8-16.

Peng, H., J. Zhang, L. Lu, G. Tang, B. Yan, X. Xiao \& Y. Han 2017. Eco-efficiency and its determinants at a tourism destination: A case study of Huangshan National Park, China. Tourism Management 60: 201-211.

Pickering, C.M., W. Hill, D. Newsome \& Y.F. Leung 2010. Comparing hiking, mountain biking and horse riding impacts on vegetation and soils in Australia and the United States of America. Journal of Environmental Management 91: 551-562.

Reihanian, A., N.Z.B. Mahmood, E. Kahrom \& T.W. Hin 2012. Sustainable tourism development strategy by SWOT analysis: Boujagh National Park, Iran. Tourism Management Perspectives 4: 223-228.

Repka, P. \& M. Švecová 2012. Environmental Education in Conditions of National Parks of Slovak Republic. Procedia - Social and Behavioral Sciences 55: 628-634.

Tatra National Park, 2019. Tatra National Park Available at: https://tpn.pl/zwiedzaj/turystyka/ statystyka

Thapa Karki, S. 2013. Do protected areas and conservation incentives contribute to sustainable livelihoods? A case study of Bardia National Park, Nepal. Journal of Environmental Management 128: 988-999.

Tolvanen, A. \& K. Kangas 2016. Tourism, biodiversity and protected areas - Review from northern Fennoscandia. Journal of Environmental Management 169: 58-66.
Tuvi, E.L., A. Vellak, Ü. Reier, R. Szava-Kovats \& M. Pärtel 2011. Establishment of protected areas in different ecoregions, ecosystems, and diversity hotspots under successive political systems. Biological Conservation 144: 1726-1732.

Wang, C., J. Zhang, J., Cao, H. Hu \& P. Yu 2019. The influence of environmental background on tourists' environmentally responsible behaviour. Journal of Environmental Management 231: 804-810.

Weaver, D.B. \& L.J. Lawton 2017. A new visitation paradigm for protected areas. Tourism Management 60: 140-146.

Xavier da Silva, M., A. Paviolo, L.R. Tambosi \& R. Pardini 2018. Effectiveness of Protected Areas for biodiversity conservation: Mammal occupancy patterns in the Iguaçu National Park, Brazil. Journal for Nature Conservation 41: 51-62.

Xu, F. \& D. Fox 2014. Modelling attitudes to nature, tourism and sustainable development in national parks: A survey of visitors in China and the UK. Tourism Management 45: 142-158.

Zhong, L., J. Deng, Z. Song \& P. Ding 2011. Research on environmental impacts of tourism in China: Progress and prospect. Journal of Environmental Management 92: 2972-2983.

Zhou, D.Q. \& R. Edward Grumbine 2011. National parks in China: Experiments with protecting nature and human livelihoods in Yunnan province, Peoples' Republic of China (PRC). Biological Conservation 144: 1314-1321.

\section{Authors}

\section{Paweł Religa}

is an Associate Professor and the head of the Department of Eco-engineering of Processes and Products at Kazimierz Pulaski University of Technology and Humanities in Radom, Poland. His main research interests are in the areas of green technologies and eco-management. Kazimierz Pulaski University of Technology and Humanities in Radom, Department of Processes and Products Eco-Engineering, Chrobrego 27, 26-600 Radom, Poland. E-mail: p.religa@ uthrad.pl

\section{Sylwia Adach - corresponding author}

is a PhD student in the Faculty of Building Services, Hydro and Environmental Engineering, Warsaw University of Technology, Poland. Her research focuses on anthropogenic environmental impacts in high-mountain protected areas. Warsaw University of Technology, Faculty of Building Services, Hydro and Environmental Engineering, Nowowiejska 20, 00-653 Warsaw, Poland. E-mail: sylwiaa.adach@gmail.com 